\title{
Ice scour disturbance to benthic communities in the Canadian High Arctic
}

\author{
K. E. Conlan ${ }^{1, *}$, H. S. Lenihan ${ }^{2, * *}$, R. G. Kvitek ${ }^{2, * * *}$ J. S. Oliver ${ }^{2}$ \\ ${ }^{1}$ Canadian Museum of Nature, PO Box 3443, Station D, Ottawa, Ontario K1P 6P4, Canada \\ ${ }^{2}$ Moss Landing Marine Laboratories, PO Box 450, Moss Landing, California 95039, USA
}

\begin{abstract}
Seabed scouring by ice is a large-scale disturbance to polar coasts. Grounding ice modifies seabed topography, reworks the sediment, and ploughs and crushes the seabed biota. The effects of ice scour on soft-sediment benthos were examined in Barrow Strait in High Arctic Canada. Due to the variability of ice keel depths in this area, the Barrow Strait coast was found to exhibit a gradient of ice scour disturbance to $30 \mathrm{~m}$ depth. The inshore shallows were highly scoured by the abundant shallow draft ice. Deeper water scours caused by icebergs and portions of ice shelves were less frequent. The benthos paralleled this disturbance gradient, with the inshore consisting of a disturbanceassociated fauna. Four recently formed ice scours were studied at 3 locations. Despite differences in exposure to currents and water depth, all scours were dominated by the same disturbance-associated fauna and were distinctive from the benthos outside. Scavenging amphipods and gastropods consumed bivalves that were dislodged and damaged, while predatory amphipods and opportunistic polychaetes burrowed in the gouged and displaced clays. Our expectation was that the topography of the ice scours would select for different colonizing species. However, there was no evidence of preferential occupation of the raised berms by suspension feeders or of the troughs by deposit feeders. The species that dominated the 4 scours also dominated the less recently disturbed areas of the inshore, despite the fact that these areas were situated 300 to $400 \mathrm{~m}$ inshore and at shallower depth. The prevalence of species that associate with ice scours indicates that ice disturbance is an important factor that molds coastal benthic zonation at this Arctic location.
\end{abstract}

KEY WORDS: Ice scour Disturbance - Benthos Arctic

\section{INTRODUCTION}

Natural physical disturbance can have a major influence on both aquatic and terrestrial communities. Effects include opening of cleared patches, alteration of physico-chemical characteristics, opportunity for colonization by different species, altered community structure, and changed species interactions (Sousa 1984, Pickett \& White 1985). Effects on the marine environment have been reviewed by Sousa (1985) for

-E-mail:kconlan@mus-nature.ca

Present addresses:

"Institute of Marine Sciences, The University of North Carolina at Chapel Hill, Morehead City, North Carolina 28557, USA

-.Earth System Science and Policy Institute, California State University Monterey Bay, 100 Campus Center, Seaside, California 93955, USA intertidal communities, Connell \& Keough (1985) for coral reefs, and Hall (1994) for soft sediment benthos. Common natural physical agents of seafloor disturbance are water motion, altered water temperature, unstable seabed, settling sediment, biotic foraging activity, and bioturbation (Sousa 1984, Connell \& Keough 1985, Hall 1994J. On polar coasts, the major chronic disturbance to both the shore and seafloor is scouring by grounding drift ice and pressure ridges. These erode hard and soft substrates alike, producing long scrapes and gouges, plough-shaped indentations, and basin-shaped depressions. Ice scour disturbance to soft sediments is a regular, predictable event on polar coasts. It differs from other such disturbances by ploughing and overturning the sediment and altering seabed topography, sometimes considerably. Icebergs have been known to scour a swath of seabed as wide as $1375 \mathrm{~m}$ and gouge an incision as deep as $11.5 \mathrm{~m}$ 
(Lewis \& Blasco 1990). On deep seafloor, such disturbances may take millennia to disappear (Pereira et al. 1985, Josenhans \& Woodworth-Lynas 1988).

The motion that ice scour can shape both the geology and biology of polar coasts was expressed by Darwin in 1837 (Levere 1993). Since then, considerable investigation of the physical effects of ice scour has been made, spurred by concerns for potential effects on man-made structures on the seabed (for reviews, see Barnes \& Reimnitz 1974, Reimnitz \& Barnes 1974, Reimnitz et al. 1977, Barnes et al. 1984, Weeks et al. 1984, Gilbert \& Pedersen 1987, Clark 1990). The impact of ice scour may be similar to the effects of such anthropogenic physical disturbances as seabed dredging and trawling (Messieh et al. 1991, Thrush et al. 1995, Currie \& Parry 1996).

Ice scouring is a large-scale coastal sediment reworking event on both the Arctic and Antarctic coasts. The coasts of Arctic and Atlantic Canada, Alaska, Russia, Svalbard, Norway, the Barents Sea, and Greenland, and the full coast of Antarctica are all vulnerable to ice disturbance. This amounts to some $149000 \mathrm{~km}$ of coast (Munro 1988, Kurian 1989). In the Arctic, the Beaufort Sea is $100 \%$ scoured by pressure ridges and multiyear ice keels from shore to $40 \mathrm{~m}$ depth, and scouring reaches as deep as $72 \mathrm{~m}$ (Lewis \& Blasco 1990). At 6 to $14 \mathrm{~m}$ water depth, the Beaufort seabed can be completely reworked within 50 yr (Reimnitz et al. 1977). On the Canadian Atlantic coast, icebergs from Greenland and the eastern Canadian Arctic scour as deep as $230 \mathrm{~m}$ (Lewis \& Blasco 1990). The Antarctic ice shelves have produced 70000 icebergs (more than $10 \mathrm{~m}$ wide) between 1981 and 1985 (Lien et al. 1989). These have scoured the seabed to water depths of up to $500 \mathrm{~m}$ (Barnes \& Lien 1988, Lien et al. 1989). Relict Pleistocene scours are still visible on the Canadian Atlantic seabed to $700 \mathrm{~m}$ depth (Pereira et al. 1985, Josenhans \& Woodworth-Lynas 1988), and iceberg scours are clearly visible on the former bed of glacial Lake Agassiz in central Canada (Woodworth-Lynas \& Guigné 1990). During glacial periods, ice scouring would have reached considerably lower latitudes, to as low as $40^{\circ} \mathrm{N}$ in the North Atlantic (Bond et al. 1992).

Most information on the biological consequences of ice scour comes from intertidal habitats or rocky shores. In the subarctic and subantarctic intertidal zones, diversity is considerably reduced by ice scour and ephemeral algae quickly colonize denuded areas (Ellis \& Wilce 1961, Kauffman 1977, O'Clair 1981, Bolton 1983, Gordon \& Desplanque 1983, Keats et al. 1985, Wilson 1988, Hooper \& Whittick 1990, McCook \& Chapman 1993). Crevices on rocky shores provide refuges for recolonization (O'Clair 1981, Heine 1989). If scouring is sufficiently frequent, long-lived species with delayed reproduction are prevented from col- onizing (Robertson \& Mann 1984, Wethey 1985, Peck \& Bullough 1993). Overall species diversity can be enhanced through removal of dominant competitors and clearing of patches for colonization by other species (DeLaca \& Lipps 1976, Keats et al. 1985). Plant morphology can be altered by regular ice pruning (Mathieson et al. 1982). Ice detachment and rafting can introduce biota to new areas (Mathieson et al. 1982). while ice-damaged biota can provide nutrient supplies to other areas after rafting, deposition, and decomposition (Mathieson et al. 1982). In the Gulf of St. Lawrence, Canada, snow geese use ice-scoured depressions in marshes for foraging (Bélanger \& Bédard 1994, 1995).

Recent work by Lenihan \& Oliver (1995) on subtidal, soft sediment infauna in McMurdo Sound, Antarctica, showed that iceberg scouring removes late successional species and creates opportunity for colonization by early successional species. The purpose of our study was to further this analysis in a different soft-sediment environment (Barrow Strait, in the Canadian High Arctic). Pressure ridges and single- and multiyear drift ice are abundant along the eastern Canadian Arctic coast (Lewis \& Blasco 1990). Less abundant deep draft icebergs and portions of ice shelves originate in Greenland and the northern Canadian Arctic archipelago (Lewis \& Blasco 1990). Due to the variability of ice keel depths, we predicted that the Barrow Strait coast would exhibit a gradient of ice scour disturbance with depth, with the inshore shallows being highly scoured by the abundant shallow draft ice. Deeper water scours offshore would be less frequent. The benthos should parallel this disturbance regime, with the inshore consisting of a disturbance associated fauna similar to that found by Lenihan \& Oliver (1995). However, since most Arctic benthic species have depth ranges that span the ice scour zone in Barrow Strait (0 to $30 \mathrm{~m}$ ) (Macpherson 1971, Curtis 1972, Sekerek et al. 1976, Lubinsky 1980, Welch et al. 1992, Aitken \& Fournier 1993), we predicted that deep water scours would have a species composition similar to that of the inshore benthos, in spite of separation and differences in depth. We also predicted that the topography of the ice scours would select for different colonizing species. Marine invertebrates preferentially colonize seabeds using a variety of physical, chemical, and biological cues including seabed topography (VanBlaricom 1982, Oliver \& Slattery 1985, Oliver et al. 1985). Suspension feeders could predominate on the berms of sediment pushed up by the ice, which would elevate the substrate in the water column. The troughs could act as catchment basins for detritus, and favor deposit feeders.

We assessed scour disturbance along the Barrow Strait coast near the Hamlet of Resolute Bay, Northwest Territories, Canada. We determined scour distribution and compared the biota along a gradient of 
depths in 3 locations, using 4 scours. This is part of a larger study determining the impact of ice scour and sequence and rate of recolonization and scour degradation. Other publications from this study are Fournier \& Conlan (1994) and Kvitek et al. (1998). Our results will improve our understanding of the effects of a common and widespread natural disturbance to the benthos of polar oceans.

\section{MATERIALS AND METHODS}

Fig. 1 shows the Barrow Strait study area along the southern coast of Cornwallis Island. This area was chosen for its accessibility and good visibility for scuba divers. The glacial clay sediment retained a clear record of scour events, such that the raised berms and incised troughs of ice scours were clearly discernable from level, unscoured areas. Criteria for recency of scour were the degree of weathering of the scour berms and troughs (sharp berms, no subsidence of sediment, presence of ice impressions and grooves in the trough) and the presence of dislodged and damaged fauna lying on the surface. Physical parameters of the scours, such as berm height, incision depth, trough length, and water depth, were measured by scuba divers. Currents in Resolute Bay and Barrow Strait were measured by 3 replicate S-4 current meters placed on the seabed for $24 \mathrm{~h}$. Distance from shore was determined from aerial observation and differential GPS (Global Positioning System). The scours were mapped by sidescan sonar using an EG\&G 260TH Dual Frequency $(100 / 500 \mathrm{kHz})$ sidescan sonar. Bathymetry was determined using a $208 \mathrm{kHz}$ Innerspace 448 digital fathometer. Amount of seabed disturbance was calculated from sidescan sonar images taken in August 1996 along the Barrow Strait coast from Cape Martyr to the mouth of Resolute Bay. Area of sidescan coverage was from 5 to $50 \mathrm{~m}$ depth. Three $100 \mathrm{~m}$ wide depth transects were selected on records that covered uniformly sloping seabed from inshore to $50 \mathrm{~m}$ depth. Disturbance was calculated as the number of grid points out of a total of 38 that touched a scour trough or berm on the sidescan images at each $25 \mathrm{~m}$ interval. This method had a $5 \%$ error rate, based on repeat measurements of the same transect. Old scour marks, which are still physically recognizable but are biologically indistinguishable from reference seabed (Conlan unpubl. data), were designated as biologically undisturbed. Ongoing assessment of scour degradation rate indicates that these scours are over 50 yr old (Conlan unpubl. data).

Fauna were sampled inside and in the proximity of 2 scours in Resolute Bay and 1 each in Assistance Bay and Barrow Strait (Fig. 1). These scours were located 300 to $400 \mathrm{~m}$ offshore. All sampling occurred in August 1991, during which time weather and ice conditions allowed access to the seabed. Nevertheless, pack ice inundations made the study sites inaccessible for more than $60 \%$ of the field season. The opportunity to replicate scours was limited by the large amount of underwater search time needed to locate scours that were relatively large, distinct, and obviously recent in origin.

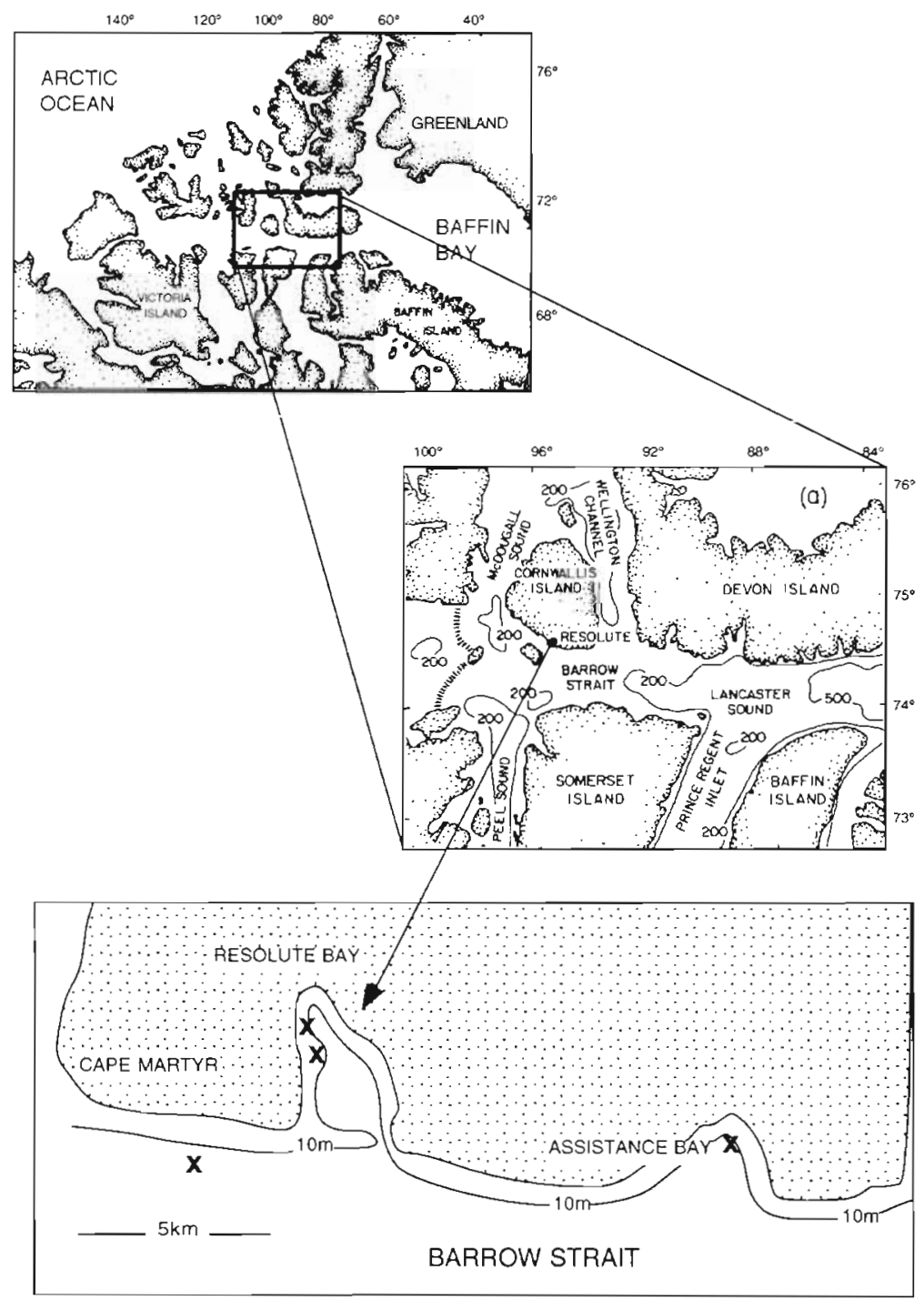

Fig. 1 The 3 study areas on the coast of Cornwallis Island in High Arctic Canada: Assistance Bay, Resolute Bay, and Barrow Strait between Cape Martyr and the mouth of Resolute Bay. $\mathbf{x}$ : scour locations 
Each of the 4 scours was sampled for benthic fauna on the trough, berm, and at 2 locations outside. The one outside site was next to the scour, while the other was $50 \mathrm{~m}$ away. All samplers were placed haphazardly. Large epifauna were counted by divers in 4 replicate $1 \mathrm{~m} \times 10 \mathrm{~m}$ transects. The transects were placed along depth contours in order to maintain a constant sampling depth. The siphons of large individuals of the bivalves Mya truncata and Serripes groenlandicus were counted in 4 replicate $1 \mathrm{~m}^{2}$ quadrats. Size frequency was measured from bivalves that were suction sampled in $1 \mathrm{~m}^{2}$ of seabed to $20 \mathrm{~cm}$ sediment depth. Small macrofauna were collected with 6 replicate $0.0075 \mathrm{~m}^{2}$ cores to $10 \mathrm{~cm}$ sediment depth. To compare community composition of the offshore scours to that of the inshore shallows, the 2 sampling sites outside each scour were extended inshore and offshore as depth transects. Six replicate core samples were taken along each transect at $3 \mathrm{~m}$ depth intervals from 3 to $15 \mathrm{~m}$ at sites that had not obviously been recently disturbed. Criteria for undisturbed conditions were presence of large kelps, even terrain, lack of ice scour marks, and cobbles with dense cover of coralline algae. These are termed 'outside' sites herein. Sediment samples were taken at each site and analyzed for grain size distribution by standard sieve methods.

The bivalve suction samples and the core samples for small fauna were sieved on a $0.5 \mathrm{~mm}$ mesh. The suctioned bivalves were sorted into species, enumerated, and weighed after drying on absorptive tissue for $1 \mathrm{~min}$ (damp-dry) while alive. The core-sampled fauna were fixed in 5\%-formalin-seawater, preserved in $70 \%$ glycerated ethanol, returned to the lab, microscopically sorted and identified to the lowest possible taxonomic level, enumerated, and weighed damp-dry. Feeding and burrowing characteristics of the fauna were determined from Reid \& Reid (1969), Stanley (1970), Bernard (1979), Fauchald \& Jumars (1979), Barnes (1980), E. L. Bousfield (Royal Ontario Museum pers. comm.), and J. Fournier and A. Martel (Canadian Museum of Nature pers. comm.).

Two-way ANOVA was applied to test for significant differences in abundance of large scuba-surveyed fauna, using the 4 scours and the substrate types (outside, berm, and trough) as crossed, fixed factors. Normality was tested using the Kolmogorov-Smirnov test, and heterogeneity of variances was tested with a Levene Median test. $\log _{10}(x+1)$ or sqrt $(x+0.5)$ transformations were applied to achieve normality and equal variance. Post hoc multiple comparisons within main effects were made using the Tukey test. The significance level for all tests was $p<0.05$.

Multivariate analyses were applied to the core collections of small fauna (which constituted the bulk of benthic abundance). The data were analysed using the
PRIMER software package described in Clarke (1993). Dominance-diversity was computed with the DOMPLOT program as cumulative dominance on the total faunal matrices for each location ( $k$-dominance curves Lambshead et al. 1983). The degree of multivariate dispersion of the replicates in each site was determined by the MVDISP procedure (Warwick \& Clarke 1993). Non-metric multidimensional scaling (MDS) (Kruskal 1964) and UPGMA (unweighted pair-group method using arithmetic averages; Sokal \& Mitchener 1958) cluster analysis using the Bray-Curtis (1957) similarity coefficient were applied to $\log _{10}(x+1)$-transformed abundances following removal of taxa that occurred in less than $5 \%$ of the samples. Environmental variables were linked to the multivariate community patterns using the BIO-ENV program described in Clarke \& Ainsworth (1993). Differences among the scours were computed by ANOSIM, a multivariate form of ANOVA described in Clarke (1993). Species responsible for the major groups generated by cluster analysis were determined with the SIMPER program.

\section{RESULTS}

\section{Physical characteristics}

The coastal seabed in the Barrow Strait study region is a mixed glacial till covered by a cobble veneer. Scouring removes the cobble cover and exposes the underlying clay. At $20 \mathrm{~m}$ water depth, the glacial till is about $5 \mathrm{~m}$ in thickness above the underlying bedrock. This cover is reduced to near zero at 0 to $5 \mathrm{~m}$ water depth. The seabeds of Assistance and Resolute Bays are also a mixed glacial till, but lack the cobble veneer. The 3 areas differ somewhat in that Resolute Bay has little current (not detectable over 1 tidal cycle in August 1994) and is protected from scouring beyond $11 \mathrm{~m}$ depth by a sill at the mouth (Fig. 1). Assistance Bay resembles Resolute Bay in aspect, but is not protected from deep draft ice by a sill. Barrow Strait has tidal currents at the sediment surface that reach $31 \mathrm{~cm}$ $\mathrm{s}^{-1}$ (measured over 1 tidal cycle in August 1994) and receives the full range of scour from small annual ice to large icebergs and multiyear ice keels.

Fig. 2 shows the process by which a moving ice keel scours the seabed. The incision left by the ice is the scour trough, and the mounds of sediment pushed up to either side are the scour berms. Uneven keels may produce parallel grooves in the trough, and movement pressures may create fractures in the trough. Ice keels may also wallow in a stationary position on the seabed, in which case a more circular pit may be formed.

Fig. 3 shows the intensity of scouring observed along the 3 depth transects in Barrow Strait. As predicted, 


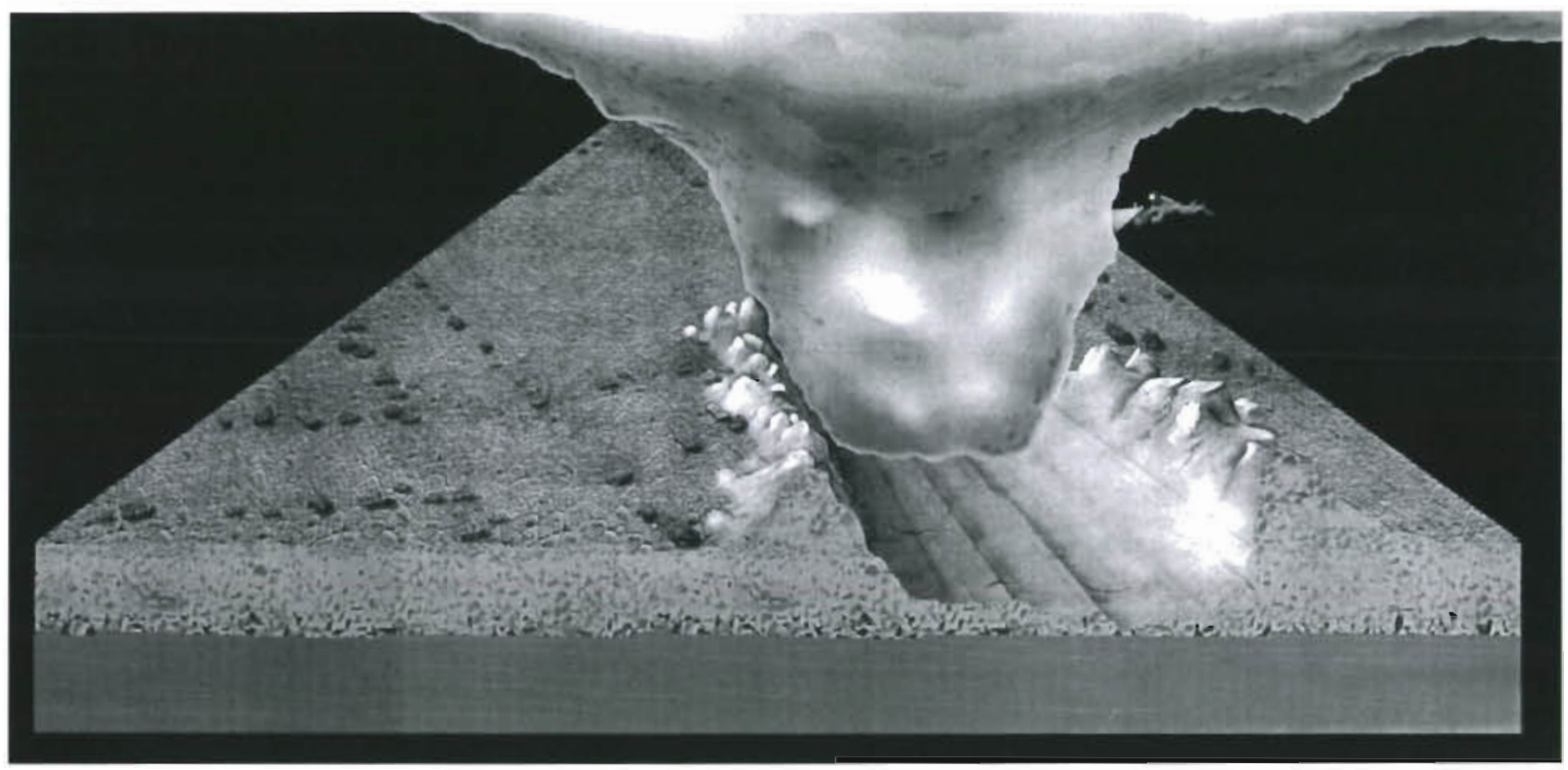

Fig. 2. Process of seabed scouring in Barrow Strait, showing the scour trough incised by the ice keel and the berms of sediment pushed up to either side. Parallel grooves produced by the uneven keel form in the scour trough, along with periodic fractures. The seabed is mixed glacial clay overlying bedrock. Remains of old scours appear as parallel rows of boulders left of the now eroded berms

scours were most abundant inshore and declined in frequency offshore. Seabed at water depths of 0 to $5 \mathrm{~m}$ was nearly $100 \%$ scoured, and 26 to $100 \%$ scoured at 6 to $10 \mathrm{~m}$. Diver observation and sidescan images indicated that the incisions were usually less than $0.5 \mathrm{~m}$ deep, and the scours tended to be narrow ( $<5 \mathrm{~m}$ wide).

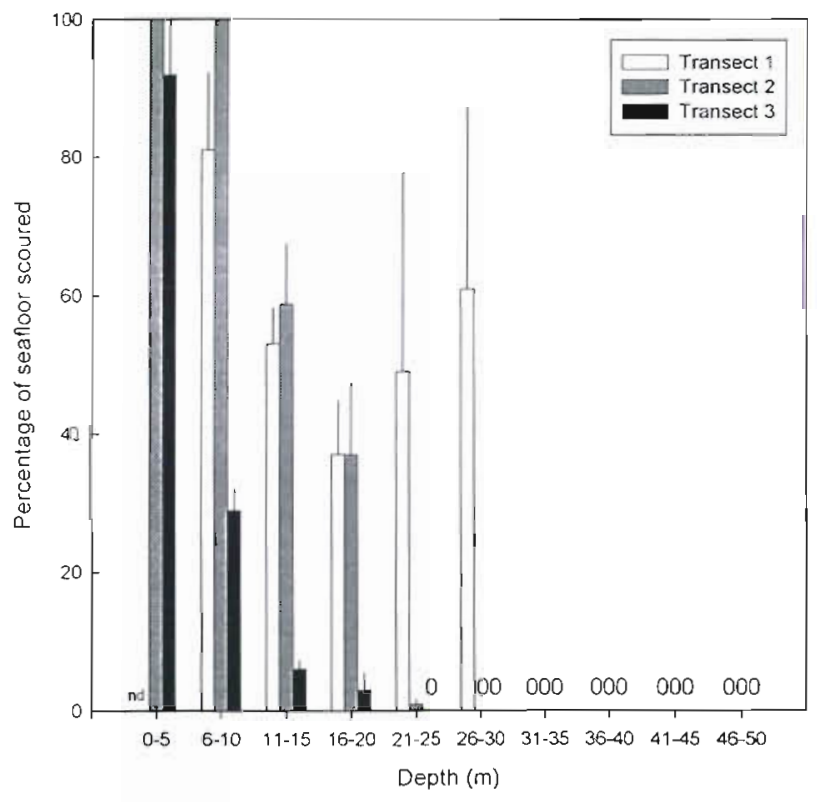

Fig. 3. Percentage of seafloor scoured $( \pm \mathrm{SE})$ in three $100 \mathrm{~m}$ wide belt transects in Barrow Strait. nd = no data
The occurrence of pitting was common inshore, resulting from tidal lifting and grounding of ice. Despite the apparent $100 \%$ scour frequency inshore as shown by sidescan sonar, finer resolution by divers indicated areas of dense kelp cover between the scours. Diver observation of the ice-scouring process showed that the ice crushed the kelp, tore the blades from the stipes, or removed the algae entirely. Thus, areas that were densely covered with long-bladed kelp were considered to have not been recently scoured and were used as reference sites for biological sampling. At 11 to $30 \mathrm{~m}$, the amount of seabed scoured was highly variable. This was due to the presence of infrequent, but large, scours. Transect 1 crossed such a scour, which paralleled the shore and was $100 \mathrm{~m}$ wide. This scour accounts for the increase in scouring seen at 21 to $30 \mathrm{~m}$ in Fig. 3. Scours at this depth typically incised 0.5 to $1.0 \mathrm{~m}$ of sediment, with the greatest penetration being $2.5 \mathrm{~m}$. From 30 to $50 \mathrm{~m}$ depth, scours were rare and often subdued in contour, suggesting that they were old. Sidescanning in Resolute Bay revealed that the seabed was more often characterized by the pitting and scraping of stationary, wallowing ice keels than by long gouges. Scouring was restricted to depths less than $11 \mathrm{~m}$ by the sill at the mouth of the bay. Assistance Bay was not surveyed by sidescan sonar. Diver observation indicated a mix of pitting and longer scrapes.

Physical characteristics of the 4 scours used for biological study are summarized in Table 1 . The scours were located 300 to $400 \mathrm{~m}$ offshore. Water depths 
Table 1. Physical characteristics of the 4 ice scours

\begin{tabular}{|lccccccrc|}
\hline Location & $\begin{array}{c}\text { Water } \\
\text { depth } \\
(\mathrm{m})\end{array}$ & $\begin{array}{c}\text { Distance } \\
\text { from shore } \\
(\mathrm{m})\end{array}$ & $\begin{array}{c}\text { Scour } \\
\text { length } \\
(\mathrm{m})\end{array}$ & $\begin{array}{c}\text { Scour } \\
\text { width } \\
(\mathrm{m})\end{array}$ & $\begin{array}{c}\text { Average } \\
\text { berm } \\
\text { height }(\mathrm{m})\end{array}$ & $\begin{array}{c}\text { Average } \\
\text { incision } \\
\text { depth }(\mathrm{m})\end{array}$ & $\begin{array}{c}\text { Sediment grain } \\
\text { size (mean phi) } \\
\text { Berm } \\
\text { Trough }\end{array}$ \\
\hline Resolute Bay & 6 & 300 & 40 & 3 & 1.0 & 0.25 & 2.33 & 2.34 \\
Resolute Bay & 9 & 300 & 13 & 13 & 1.5 & 1.0 & 0.58 & 2.91 \\
Assistance Bay & 6 & 400 & 50 & 6 & 1.0 & 0.5 & -0.82 \\
Barrow Strait & 15 & 400 & 40 & $3-4$ & 1.5 & $1.5-2.0$ & 1.34 & 0.79 \\
& & & & & & & & \\
\hline
\end{tabular}

varied from 6 to $15 \mathrm{~m}$. Of the 4 , the Barrow Strait scour was at greatest water depth and incised the seabed most deeply. Each scour consisted of clay with buried cobble, gravel, and shell. All scours appeared to have been formed since ice breakup 2 wk before sampling. The Resolute and Assistance Bay scours contained uprooted and damaged clams that had not yet lost their tissue to scavengers. The Barrow Strait scour lacked dislodged infauna and therefore was possibly older. However, like the other scours, it had sharp berms and a smooth clay trough, which contrasted with the cobble-veneered clay outside. None of the scours contained anoxic, discolored water as described by Kvitek et al. (1998).

\section{Biotic characteristics}

\section{Comparison of the scours with the outside}

Most large fauna that could be quantified by scuba diving showed low abundance within the ice scours. The large bivalves Mya truncata and Serripes groenlandicus, which were inaccessible by core collection, were quantified by a siphon count. Mean density of their siphons differed significantly among the 4 scours across the 3 substrates (outside, berm, and trough) (Table 2). Mean density was significantly greater outside the Barrow Strait scour $\left(41.8 \pm 3.7 \mathrm{~m}^{-2}\right)$ than outside the 2 Resolute Bay scours $\left(23.0 \pm 4.7 \mathrm{~m}^{-2}\right.$ and $26.0 \pm 2.8 \mathrm{~m}^{-2}$ ) (Tukey tests, $\mathrm{p}<0.05$ for both comparisons) (Table 3 ). At both locations, mean density was

Table 2. Results of 2-way ANOVA of large bivalves and buccinid gastropods. Data were log-transformed for the bivalves and untransformed for Buccinum spp. abundance

\begin{tabular}{|lrrrrrrrrr|}
\hline & \multicolumn{4}{c}{ Bivalves (siphons $\mathrm{m}^{-2}$ ) } & & \multicolumn{3}{c|}{ Buccinum spp. (ind. $10 \mathrm{~m}^{-2}$ ) } \\
& df & MS & F-ratio & p-value & df & MS & $F$-ratio & p-value \\
& 2 & 0.269 & 27.982 & $<0.001$ & 2 & 11.194 & 5.422 & 0.010 \\
Scour (a) & 2 & 6.1 .13 & 635.075 & $<0.001$ & 2 & 15.361 & 7.439 & 0.003 \\
Substrate (b) & 4 & 0.494 & 51.330 & $<0.001$ & 4 & 8.694 & 4.211 & 0.009 \\
a $\times$ b & 27 & 0.010 & & & 27 & 2.065 & & \\
Residual & & & & & & & & \\
\hline
\end{tabular}

significantly lower inside the scours than outside (post hoc Tukey tests; Table 3). Shell size-frequency analysis of suction samples at $12 \mathrm{~m}$ depth revealed that $M$. truncata was significantly smaller in Barrow Strait than in Resolute Bay $(t=3528.5, p<0.001)$. Mean shell length in Barrow Strait averaged $3.6 \pm 0.08 \mathrm{~cm}(\mathrm{n}=156)$, while in Resolute Bay it was $5.0 \pm 0.17 \mathrm{~cm}(\mathrm{n}=26)$.

The relative abundance of other large, widely dispersed fauna was also determined by scuba survey. Buccinid gastropod distribution exhibited a significant difference among scours and substrates (Table 2). However, there was not a significantly lower abundance inside the scours than outside as there was for the bivalves (Table 3). Indeed, at the Barrow Strait scour, abundance on the berm was significantly greater than abundance outside. Buccinids were found scavenging damaged individuals of Mya truncata and Serripes groenlandicus that were uprooted and lying exposed on the scours. Other scavengers present in the scours but not quantified were various lysianassid amphipods (Onisimus spp., Boeckosimus affinis, and Anonyx nugax). These amphipods were abundant inshore as well, burrowing into the sediment and descending en masse if offered damaged fauna.

Several other large invertebrates were found in relatively high abundance outside the Barrow Strait scour, but were absent or in low abundance inside the scour. These were the sea urchin Strongylocentrotus spp. ( $S$. droebachiensis and S. pallidus), the soft coral Gersemia rubriformis, the sea cucumber Cucumaria sp., infaunal anemones, and solitary tunicates. Mean abundance ranged from $155.0 \pm 19.410 \mathrm{~m}^{-2}$ for the urchins to $2.5 \pm 0.610 \mathrm{~m}^{-2}$ for the tunicates $(n=4)$. All but the urchins were entirely absent within the scour. Urchin density varied significantly with substrate (1-way ANOVA, $F=26.585, \mathrm{p}<0.001$ ), with mean density being significantly lower both on the berm and inside the trough than outside, but not significantly different between berm and trough (Tukey test, $p<0.05$ ). These species were too rare to be quantified in Resolute and Assistance Bays. 
Table 3. Mean \pm SE abundance $(n=4)$ of the species in Table 2 and post hoc Tukey test $q$-values for comparisons between outside and inside the scour. Differences are significant at $p<0.05$ ('significant; ns: not significant)

\begin{tabular}{|c|c|c|c|c|c|c|}
\hline Species & Location & Outside & Scour berm & $\begin{array}{l}\text { q (berm vs } \\
\text { outside) }\end{array}$ & $\begin{array}{l}\text { Scour } \\
\text { trough }\end{array}$ & $\begin{array}{c}\text { q (trough } \\
\text { vs outside) }\end{array}$ \\
\hline $\begin{array}{l}\text { Bivalves } \\
\text { (siphons } \mathrm{m}^{-2} \text { ) }\end{array}$ & $\begin{array}{l}\text { Resolute Bay, } 6 \mathrm{~m} \\
\text { Resolute Bay, } 9 \mathrm{~m} \\
\text { Assistance Bay, } 6 \mathrm{~m} \\
\text { Barrow Strait, } 15 \mathrm{~m}\end{array}$ & $\begin{array}{c}23.0 \pm 4.7 \\
26.0 \pm 2.8 \\
\text { No data } \\
41.8 \pm 3.7\end{array}$ & $\begin{array}{l}8.8 \pm 0.85^{a} \\
6.2 \pm 0.55^{\circ} \\
\text { No data } \\
\quad 0\end{array}$ & $\begin{array}{l}7.504^{\circ} \\
11.562^{\circ} \\
\text { No data } \\
33.156^{\circ}\end{array}$ & $\begin{array}{c}0.5 \pm 0.3^{\circ} \\
0 \\
\text { No data } \\
0\end{array}$ & $\begin{array}{l}24.498^{\circ} \\
29.040^{\circ} \\
\text { No data } \\
33.156^{\circ}\end{array}$ \\
\hline $\begin{array}{l}\text { Buccinum spp. } \\
\text { (ind. } 10 \mathrm{~m}^{-2} \text { ) }\end{array}$ & $\begin{array}{l}\text { Resolute Bay, } 6 \mathrm{~m} \\
\text { Resolute Bay, } 9 \mathrm{~m} \\
\text { Assistance Bay, } 6 \mathrm{~m} \\
\text { Barrow Strait, } 15 \mathrm{~m}\end{array}$ & $\begin{array}{l}2.0 \pm 0.9 \\
2.8 \pm 0.5 \\
\text { No data } \\
2.2 \pm 0.8\end{array}$ & $\begin{array}{l}0.5 \pm 0.5 \\
3.5 \pm 0.6 \\
\text { No data } \\
5.8 \pm 1.3\end{array}$ & $\begin{array}{c}2.088 \mathrm{~ns} \\
1.044 \mathrm{~ns} \\
\text { No data } \\
4.871^{\circ}\end{array}$ & $\begin{array}{l}1.0 \pm 0.4 \\
0.8 \pm 0.5 \\
\text { No data } \\
1.3 \pm 0.5\end{array}$ & $\begin{array}{c}1.392 \mathrm{~ns} \\
2.784 \mathrm{~ns} \\
\text { No data } \\
1.392 \mathrm{~ns}\end{array}$ \\
\hline
\end{tabular}

Fig. 4 shows the relative abundance and biomass (wet weight) of the small, core-collected fauna at the 3 sites. In the undisturbed sediments outside the scours, mean abundance ranged from 70.3 to 399.7 ind. core ${ }^{-1}$ Mean wet weight ranged from 0.3 to $25.6 \mathrm{~g} \mathrm{core}^{-1}$. In Barrow Strait abundance and biomass increased with depth. In the 2 bays no consistent trend was apparent. Within the ice scours, abundance was significantly lower than outside in the 2 scoured troughs at Resolute Bay and on the scour berm at Barrow Strait (Tukey test, $p<0.05)$. Differences in abundance between the scour and the outside sediment were not significant in Assistance Bay. Biomass was significantly lower than outside at all 3 sites, however.
While nemerteans, priapulids, sipunculids, and echinoderms (holothurians) were present outside the scours in many of the cores, over $90 \%$ of the species were polychaetes, molluscs, and crustaceans. In total, 131 taxa were identified: 33 were polychaetes, 26 were molluscs, and 52 were crustaceans. The bulk of the polychaetes were in the families Capitellidae, Cirratulidae, Hesionidae, Maldanidae, Paraonidae, Orbiniidae, Pholoidae, Phyllodocidae, Sabellidae, and Spionidae. Molluscan dominants were the gastropods Cingula castanea, Philine lima and Retusa obtusa, and the bivalves Astarte spp. (A. borealis, A. cf. montagui, and A. cf. Warhami), Axinopsida orbiculata, Macoma spp. (M. calcarea, M. loveni, and M. moesta), Muscuius ais-
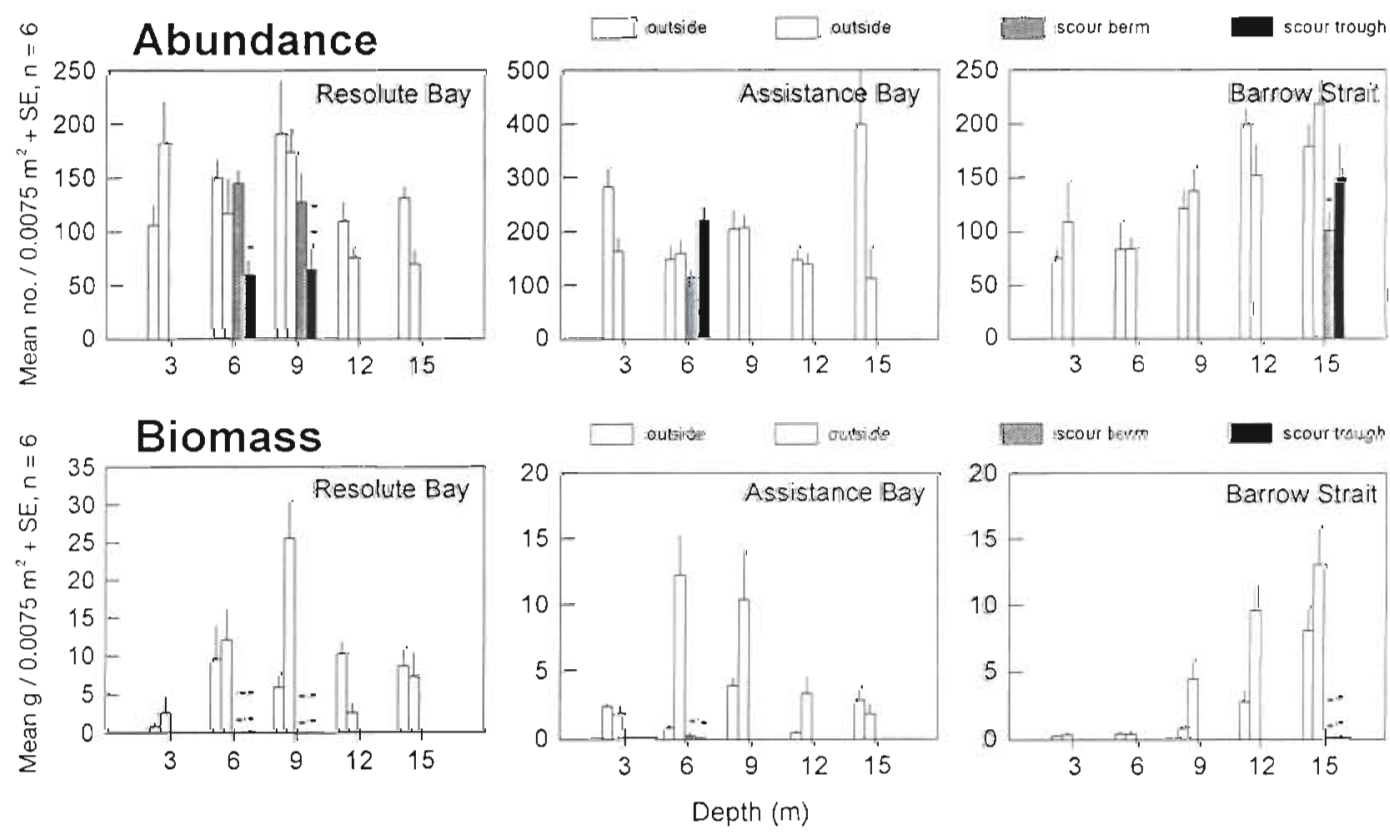

Fig. 4. Total abundance and wet weight biomass of core-collected fauna outside and inside the scoured berms and troughs at the 3 locations. Mean abundance or biomass in the scours are significantly less than outside the scours when marked by a minus sign $(-)$ (Tukey test, $\mathrm{p}<0.05$ ). A double negative indicates that abundance or biomass in the scour is significantly less than both sites outside the scour at that same depth 

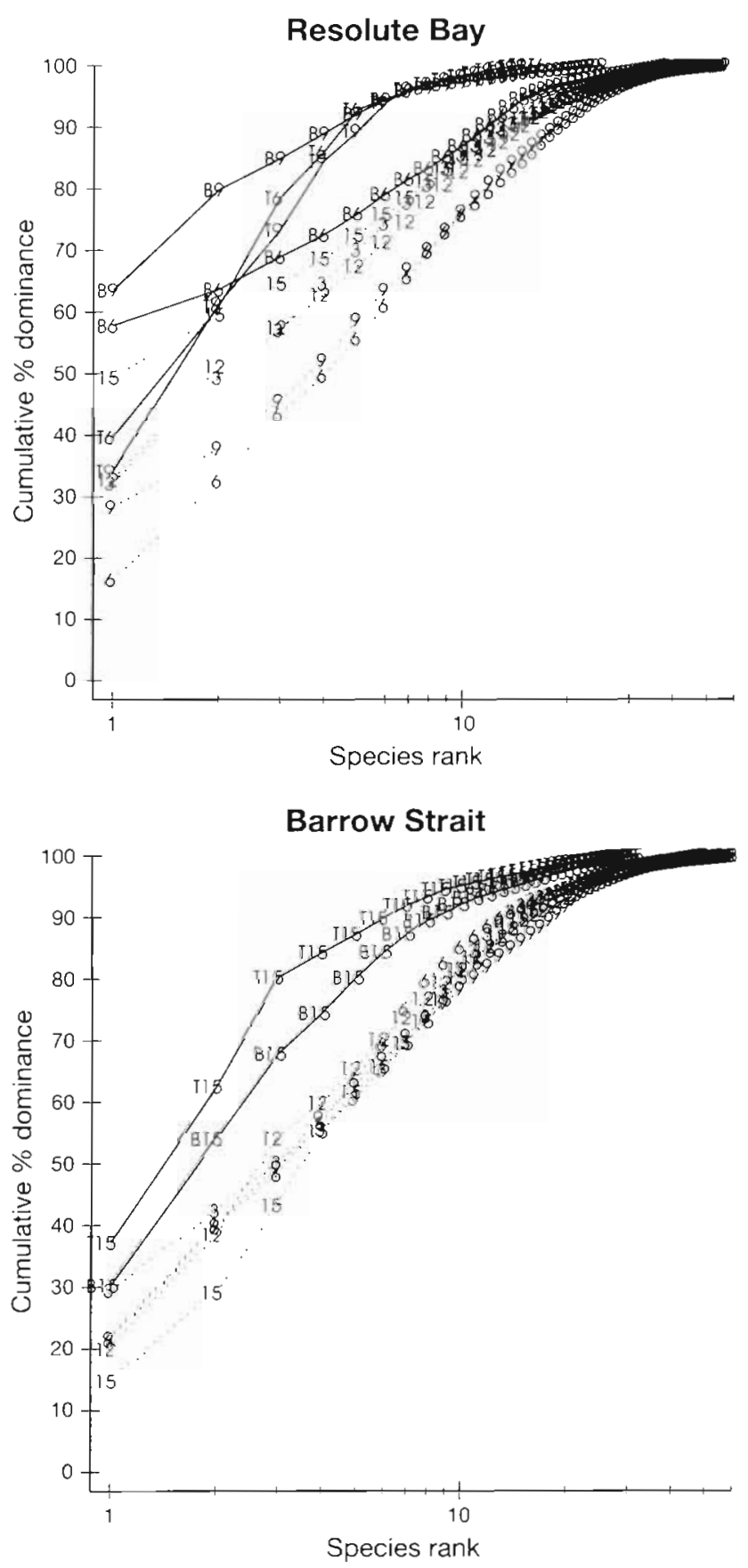

cors, Mya truncata, and Thyasira gouldi. Crustacean dominants were cumaceans, tanaids, myodocopid and podocopid ostracods, and the burrowing amphipods Monoculodes latimanus, Monoculodes vibei, Orchomene minutus, and Pontoporeia femorata. Dominancediversity plots of the samples are shown in Fig. 5. In each location, the communities of the scour troughs and berms showed lower diversity and greater species dominance than did the communities outside the scours. Among the depth transects outside the scours,

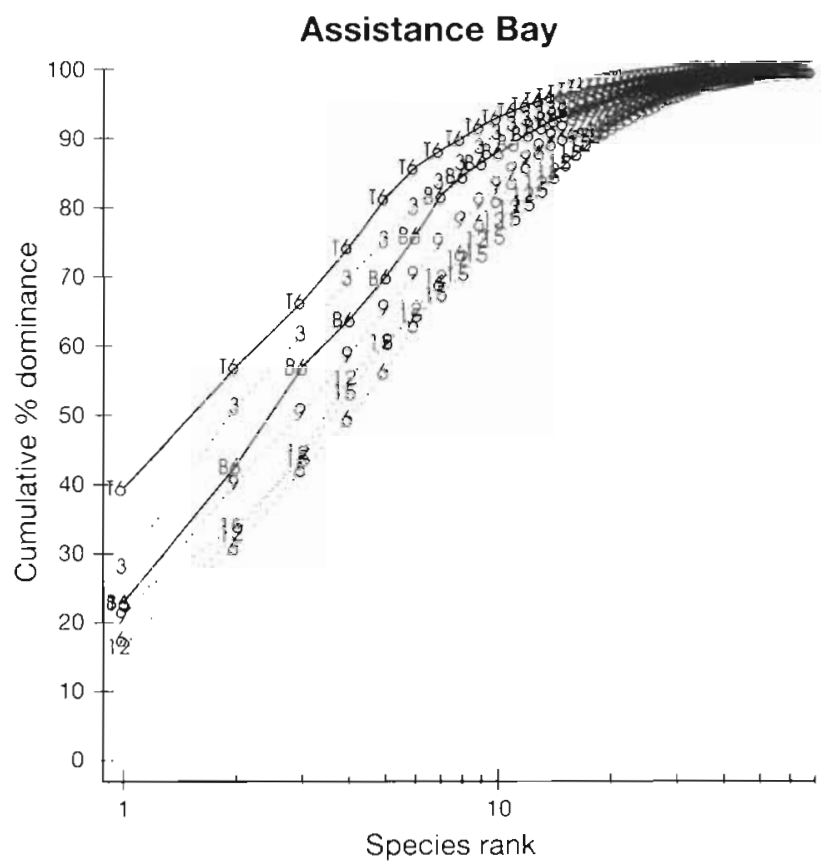

Fig. 5. Dominance-diversity curves for the core-collected species inside scour troughs $(T)$ and berms $(B)$ and at 3 to $15 \mathrm{~m}$ depths ( $3 \mathrm{~m}$ depth intervals) outside the scours in Resolute and Assistance Bays and Barrow Strait

there was generally greater species dominance at shallower depth than at deeper depth.

The degree of multivariate dispersion of the replicates at each site is shown in Table 4. Assistance Bay had the most variability in sample replicates [index of multivariate dispersion (IMD) $=0.48$ to 1.82 ]. The least variablity among replicates was in Barrow Strait (IMD $=0.24$ to 1.49). Warwick \& Clarke (1993) found that the variability of impacted sites in a number of studies was much greater than the variability of control sites. However, the ice-disturbed sites did not show a greater variability among replicates than the sites outside the scours. Among the samples taken outside the scours, the Barrow Strait samples showed a depth trend in variability, with the shallower water samples showing more variation among the replicates. There was no consistent depth trend in the Resolute and Assistance Bay samples

Ordination of the core collections by non-metric multidimensional scaling (MDS) (Fig. 6) demonstrated a change with depth in the fauna outside the ice scours. The samples taken inside the scours grouped apart from their same-depth counterparts outside and were closest in similarity to the shallow water collections. There was some separation of trough from berm samples in Resolute Bay and Barrow Strait. Analysis of all sites combined indicated that there was consider- 
Table 4. Sample sites at Resolute Bay, Assistance Bay, and Barrow Strait ordered from lowest to highest multivariate dispersion (IMD) among the replicates $(n=6)$. Ice scour samples are given in bold

\begin{tabular}{|c|c|c|c|c|c|}
\hline \multicolumn{2}{|c|}{ Resolute Bay } & \multicolumn{2}{|c|}{ Assistance Bay } & \multicolumn{2}{|c|}{ Barrow Strait } \\
\hline Site & IMD & Site & IMD & Site & IMD \\
\hline Trough $6 \mathrm{~m}$ & 0.38 & Outside $3 \mathrm{~m}$ & 0.48 & Outside $15 \mathrm{~m}$ & 0.24 \\
\hline Outside $12 \mathrm{~m}$ & 0.57 & Trough $6 \mathrm{~m}$ & 0.56 & Outside $12 \mathrm{~m}$ & 0.42 \\
\hline Outside $15 \mathrm{~m}$ & 0.62 & Outside $9 \mathrm{~m}$ & 0.72 & Outside $12 \mathrm{~m}$ & 0.69 \\
\hline Outside $9 \mathrm{~m}$ & 0.65 & Outside $9 \mathrm{~m}$ & 0.86 & Outside $15 \mathrm{~m}$ & 0.87 \\
\hline Berm 9 m & 0.78 & Outside $6 \mathrm{~m}$ & 0.88 & Outsıde $9 \mathrm{~m}$ & 0.88 \\
\hline Outside $6 \mathrm{~m}$ & 0.93 & Outside $12 \mathrm{~m}$ & 0.90 & Trough $15 \mathrm{~m}$ & 1.09 \\
\hline Outside $3 \mathrm{~m}$ & 1.05 & Outside $15 \mathrm{~m}$ & 1.00 & Outside $9 \mathrm{~m}$ & 1.16 \\
\hline Outside $12 \mathrm{~m}$ & 1.17 & Outside $3 \mathrm{~m}$ & 1.06 & Berm $15 \mathrm{~m}$ & 1.21 \\
\hline Outside $6 \mathrm{~m}$ & 1.18 & Outside $6 \mathrm{~m}$ & 1.13 & Outside $3 \mathrm{~m}$ & 1.24 \\
\hline Trough $9 \mathrm{~m}$ & 1.23 & Outside $12 \mathrm{~m}$ & 1.18 & Outside $6 \mathrm{~m}$ & 1.28 \\
\hline Outside $9 \mathrm{~m}$ & 1.29 & Berm $6 \mathrm{~m}$ & 1.37 & Outside $6 \mathrm{~m}$ & 1.44 \\
\hline Berm $6 \mathrm{~m}$ & 1.30 & Outside $15 \mathrm{~m}$ & 1.82 & Outside $3 \mathrm{~m}$ & 1.49 \\
\hline Outside $3 \mathrm{~m}$ & 1.37 & & & & \\
\hline Outside $15 \mathrm{~m}$ & 1.47 & & & & \\
\hline
\end{tabular}

Fig. 6. MDS plots of sample similarity according to species composition inside scour troughs (T) and berms (B) and at 3 to $15 \mathrm{~m}$ depths $(3 \mathrm{~m}$ depth intervals) outside the scours in Resolute (R) and Assistance $(A)$ Bays and Barrow Strait (B)

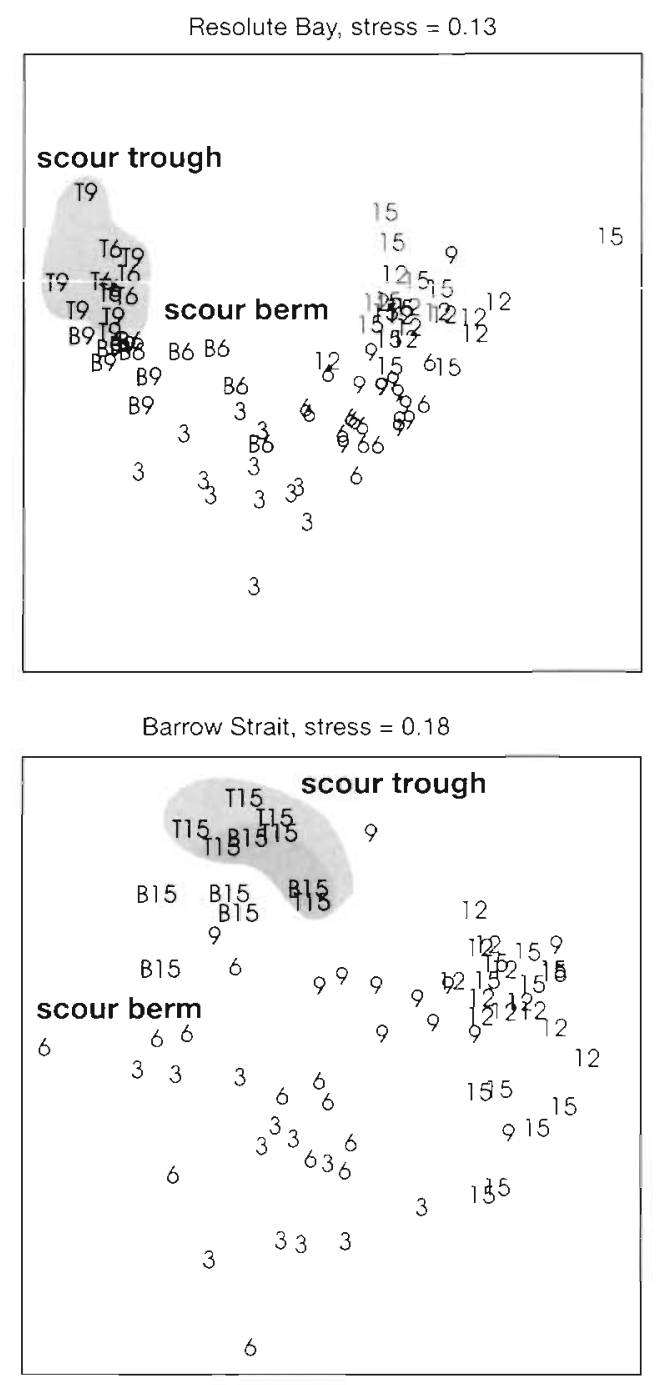

able overlap in species composition at the 3 locations. The single environmental factor that best explained sample groupings was state of disturbance [weighted Spearman or harmonic rank correlation, $r=0.441$ (BIOENV procedure)l. Sediment structure (mean phi) was least influential on sample groupings $(r=0.096)$. Disturbance and depth were the best double combination of environmental factors, but reduced the rank correlation to $r=0.396$. Addition of substrate improved the rank correlation to $r=0.424$, but this was still less than the single effect of state of disturbance.

Two-way crossed ANOSIM of the 4 scours showed that each scour differed significantly in community structure

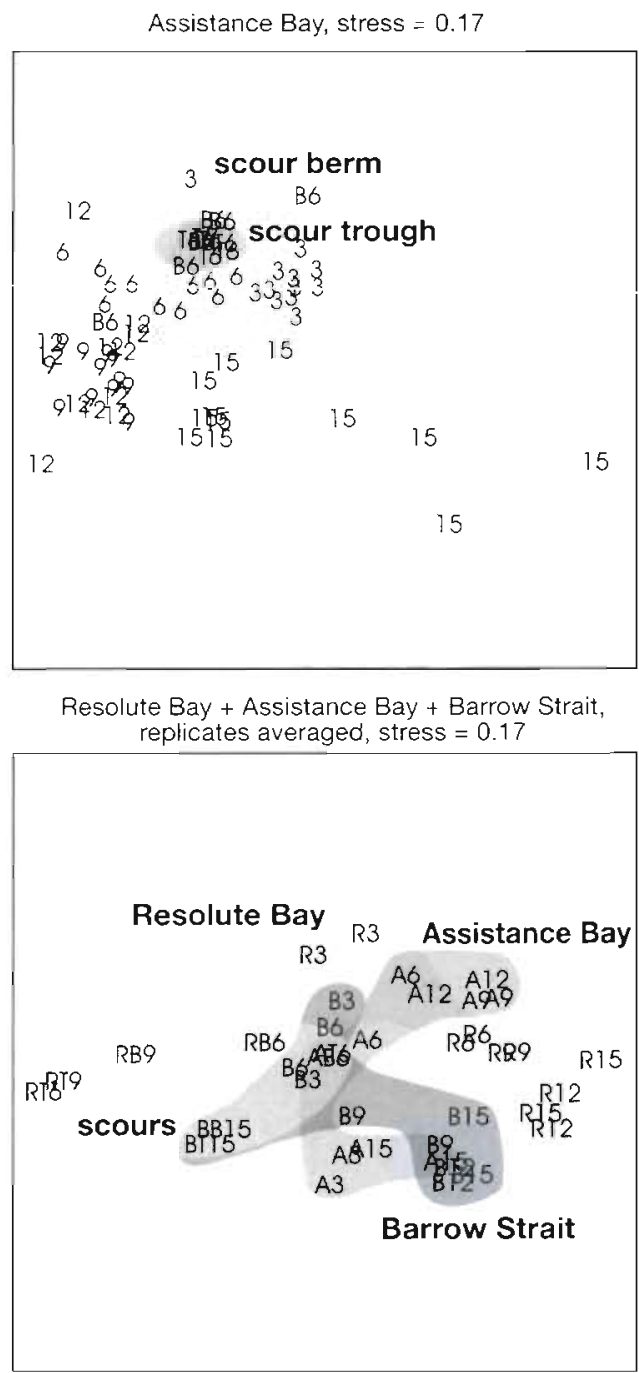


Table 5. One-way ANOSIM comparison of species composition in the 4 scours

\begin{tabular}{|c|c|c|c|c|c|}
\hline Pair comparison & R statistic & $\begin{array}{c}\text { Possible } \\
\text { permutations }\end{array}$ & $\begin{array}{c}\text { Permutations } \\
\text { used }\end{array}$ & $\begin{array}{l}\text { Significant } \\
\text { statistics }\end{array}$ & $\begin{array}{c}\text { Signuficance } \\
\text { level }(\%)\end{array}$ \\
\hline Resolute $6 \mathrm{~m}$ and Resolute $9 \mathrm{~m}$ & 0.059 & $1.352 \times 10^{6}$ & 5000 & 599 & 12.0 \\
\hline Resolute $6 \mathrm{~m}$ and Assistance $6 \mathrm{~m}$ & 0.730 & $1.352 \times 10^{5}$ & 5000 & 0 & 0 \\
\hline Resolute $6 \mathrm{~m}$ and Barrow $15 \mathrm{~m}$ & 0.662 & $1.352 \times 10^{6}$ & 5000 & 0 & 0 \\
\hline Resolute $9 \mathrm{~m}$ and Assistance $6 \mathrm{~m}$ & 0.815 & $1.352 \times 10^{6}$ & 5000 & 0 & 0 \\
\hline Resolute $9 \mathrm{~m}$ and Barrow $15 \mathrm{~m}$ & 0.691 & $1.352 \times 10^{6}$ & 5000 & 0 & 0 \\
\hline Assistance $6 \mathrm{~m}$ and Barrow $15 \mathrm{~m}$ & 0.738 & $1.352 \times 10^{6}$ & 5000 & 0 & 0 \\
\hline
\end{tabular}

from the community immediately outside $10 \%$ of permuted statistics $\geq R=0.848$, no. permutations $=5000)$. Comparison of species composition within the scours by 1 -way ANOSIM showed that the fauna within the Resolute Bay, Assistance Bay, and Barrow Strait scours differed significantly in composition from each other. However, there was no significant difference between the 2 Resolute Bay scours (Table 5).

Cluster analysis grouped the collections taken outside the scours into shallow and deep water clusters. The scour samples clustered with the shallow water samples. Species that dominated these groups are shown in Table 6 . Within the scours and the shallow water collections outside the scours, spionid and capitellid polychaetes were the species most responsible for group formation. Several other polychaetes were important as well: ampharetids, phyllodocids, sabellids, the hesionid Nereimyra punctata, and the dorvilleid Ophryotrocha spatula. Some crustaceans were also important. Two genera of amphipods, Orchomene and Monoculodes, were important in Resolute Bay. Monoculodes was important in Barrow Strait, as were cumaceans. Fauna responsible for formation of the deep water clusters were more numerous and varied. Bivalves figured more prominently than in the scours and shallows, with Axinopsida orbiculata, Macoma spp., and Musculus discors exhibiting some importance in group formation. Some polychaete families overlapped with the scour cluster, indicating that greater taxonomic distinction would be necessary for refinement of relationships. Table 6 also shows the feeding and burrowing characteristics of these fauna. The scour and shallow water clusters were dominated by deposit feeders and predators, while the deep water clusters contained a larger proportion of suspension feeders. Most of these species were subsurface burrowers. However, in the deeper water some surface living and deep-burrowing species were dominant as well.

\section{Comparison of scour berms and troughs}

Two-way crossed ANOSIM showed that the scour troughs and berms differed significantly in species composition $10 \%$ of permuted statistics $\geq R=0.390$, no, permutations $=5000$ ). However, many of the dominants were common to both troughs and berms (Table 7). Spionid and capitellid polychaetes dominated all 4 scours. The dorvilleid polychaete Ophryotrocha spatula dominated the Resolute and Assistance Bay scours. The amphipods Monoculodes spp. and Orchomene spp. dominated the Resolute Bay and Barrow Strait scours. Most of the dominants were subsurface dwelling deposit feeders. Contrary to our expectation, the berms were not populated by suspension feeders.

\section{DISCUSSION}

The results showed that ice scour had a significant impact on the benthos in Barrow Strait. Species composition inside the scours was markedly different from outside, and was dominated by small polychaetes and crustaceans. Ice scouring eliminated or damaged large organisms such as kelp, sea urchins, and bivalves. Considering that ice scour affects the full Arctic coastline, this loss may be of ecological significance. Laminarian kelp are large primary producers and provide cover for associated organisms. Sea urchins control the distribution of kelps and coralline algae (Vadas 1977. Larson et al. 1980, Keats et al. 1984). The large bivalves Mya truncata and Serripes groenlandicus are a significant energy resource for walrus (Welch et al. 1992). These and smaller bivalves deposit undigested phytoplankton, which then enters the deposit-feeding food web (Welch et al. 1992).

Some species were found in elevated numbers inside the scours. Buccinid gastropods and lysianassid amphipods were found scavenging the remains of damaged and dislodged bivalves. Deposit feeding polychaetes and scavenging crustaceans were abundant both within the scours and in the shallows outside the scours. Suspension feeders and predators were more abundant in deeper water where scouring was less evident. Thus, ice scouring appears to favor deposit feeders and scavengers. This differential effect of disturbance on certain feeding guilds has also been 
Table 6. Species accounting for $75 \%$ of the average similarity within the major groups identified by cluster analysis. Species are ordered from the greatest contribution to the least. Taxonomic category, feeding guild, and benthic distribution of these species follow in the same order

\begin{tabular}{|c|c|c|c|c|c|}
\hline \multicolumn{3}{|c|}{ Scours + shallow water samples outside the scours } & \multicolumn{3}{|c|}{ Deep water samples outside the scours } \\
\hline $\begin{array}{l}\text { Resolute Bay } \\
\text { (scours) }\end{array}$ & $\begin{array}{l}\text { Assistance Bay } \\
(\text { scour }+3-6 \mathrm{~m})\end{array}$ & $\begin{array}{l}\text { Barrow Strait } \\
(\text { scour }+3-9 \mathrm{~m})\end{array}$ & $\begin{array}{l}\text { Resolute Bay } \\
(3-15 \mathrm{~m})\end{array}$ & $\begin{array}{l}\text { Assistance Bay } \\
(6-15 \mathrm{~m})\end{array}$ & $\begin{array}{l}\text { Barrow Strait } \\
(9-15 \mathrm{~m})\end{array}$ \\
\hline \multicolumn{6}{|c|}{ Taxa } \\
\hline Spionidae & Spionidae & Capitellidae & Cirratulidae & Syllidae & Cirratulidae \\
\hline Orchomene spp. & Capitellidae & Spionidae & Spionidae & Nereimyra punctata & Spionidae \\
\hline \multirow[t]{9}{*}{ Monoculodes spp. } & Ampharetidae & Phyllodocidae & Axinopsida orbiculata & Myodocopid Ostracoda & Capitellidae \\
\hline & Phyllodocidae & Cumacea & Capitellidae & Pholoe minuta & Nemertea \\
\hline & Nereimyra punctata & Monoculodes spp. & Syllidae & Spionidae & Axinopsida orbiculata \\
\hline & Ophryotrocha spatula & Nemertea & Nereimyra punctata & Capitellidae & Macoma spp. \\
\hline & Sabellidae & Nereimyra punctata & Sabellidae & Phyllodocidae & Pholoe minuta \\
\hline & & & Phyllodocidae & Cirratulidae & Tanaidaea \\
\hline & & & Pholoe minuta & Ampharetidae & Cumacea \\
\hline & & & Retusa obtusa & Musculus discors & Myodocopid Ostracoda \\
\hline & & & Macoma spp & Sabellidae & \\
\hline \multicolumn{6}{|c|}{ Taxonomic group } \\
\hline Polychaete & Polychaete & Polychaete & Polychaete & Polychaete & Polychaete \\
\hline Crustacean & Polychaete & Polychaete & Polychaete & Polychaete & Polychaete \\
\hline \multirow[t]{9}{*}{ Crustacean } & Polychaete & Polychaete & Bivalve & Crustacean & Polychaete \\
\hline & Polychaete & Crustacean & Polychaete & Polychaete & Nemertean \\
\hline & Polychaete & Crustacean & Polychaete & Polychaete & Bivalve \\
\hline & Polychaete & Nemertean & Polychaete & Polychaete & Bivalve \\
\hline & Polychaete & Polychaete & Polychaete & Polychaete & Polychaete \\
\hline & & & Polychaete & Polychaete & Crustacean \\
\hline & & & Polychaete & Polychaete & Crustacean \\
\hline & & & Gastropod & Bivalve & Crustacean \\
\hline & & & Bivalve & Polychaete & \\
\hline \multicolumn{6}{|c|}{ Feeding guild } \\
\hline Deposit feeder & Deposit feeder & Deposit feeder & Deposit feeder & Predator & Deposit feeder \\
\hline Scavenger & Deposit feeder & Deposit feeder & Depusit feedei & Predator & Deposit feeder \\
\hline \multirow[t]{9}{*}{ Predator } & Deposit feeder & Predator & Suspension feeder & Suspension feeder & Deposit feeder \\
\hline & Predator & Suspension feeder & Deposit feeder & Predator & Predator \\
\hline & Predator & Predator & Predator & Deposit feeder & Suspension feeder \\
\hline & Deposit feeder & Predator & Predator & Deposit feeder & Deposit feeder \\
\hline & Suspension feeder & Predator & Suspension feeder & Predator & Predator \\
\hline & & & Predator & Deposit feeder & Suspension feeder \\
\hline & & & Predator & Deposit feeder & Suspension feeder \\
\hline & & & Unknown & Suspension feeder & Suspension feeder \\
\hline & & & Deposit feeder & Suspension feeder & \\
\hline \multicolumn{6}{|c|}{ Benthic distribution } \\
\hline Subsurface & Subsurface & Subsurface & Subsurface & Surface & Subsurface \\
\hline Subsurtace & Subsurface & Subsurface & Subsurface & Subsurface & Subsurface \\
\hline \multirow[t]{9}{*}{ Subsurface } & Subsurface & Subsurface & Subsurface & Surface & Subsurface \\
\hline & Subsurtace & Subsurface & Subsurface & Subsurface & Surface \\
\hline & Subsurface & Subsurface & Surface & Subsurface & Subsurface \\
\hline & Subsurface & Surface & Subsurface & Subsurface & Deep \\
\hline & Deep & Subsurface & Deep & Subsurface & Subsurface \\
\hline & & & Subsurface & Subsurface & Subsurface \\
\hline & & & Subsurface & Subsurface & Subsurface \\
\hline & & & Surface & Surface & Surface \\
\hline & & & Deep & Deep & \\
\hline
\end{tabular}

observed in dredge and trawl tracks (Brylinsky et al. 1994, Currie \& Parry 1996) and in areas of organic enrichment (Pearson \& Rosenberg 1978, Rhoads \& Boyer 1982, Weston 1990).

The scour communities closely resembled the inshore, shallow water benthos outside the scours. This similarity was in spite of the 300 to $400 \mathrm{~m}$ separation of the scours from the inshore area, differences in water depth (the scours were 3 to $12 \mathrm{~m}$ deeper), and differences in kelp cover (the scours lacked kelp cover, while the inshore samples had nearly 100\% kelp cover). Cumaceans, the amphipods Monoculodes spp. and Orchomene spp., and spionid, capitellid, dorvilleid, phyllodocid, ampharetid, hesionid, and sabellid polychaetes were common to both the scours and the inshore area. Of the 3 environmental factors measured 
(disturbance, depth, and sediment type), ice disturbance best accounted for the species distributions in the samples. The presence of abundant kelp inshore suggested that the shallow water sites had not been recently disturbed by ice. However, the resemblance of the inshore fauna to the scour fauna was likely scour related. The sidescan mosaics clearly showed a high density of scours inshore. Species characteristic of recent disturbance will persist where the frequency of disturbance is high (Petraitis et al. 1989). Considering the abundance of drift ice and pressure ridges in the Arctic and Antarctic (Barnes \& Lien 1988, Lien et al. 1989, Lewis \& Blasco 1990), ice scour disturbance mus: be a major factor in defining inshore community structure at both poles.

Our expectation was that elevation of sediment into berms by the ice would favor suspension feeders, while the scour trough would be depositional, and hence favor deposit feeders. This hypothesis was not supported by any of the 4 scours. Berms and troughs were dominated by mostly deposit-feeding, scavenging, or predatory polychaetes and crustaceans.

A summary of the contrasts between the Barrow Strait scour and the seabed outside is illustrated in Fig. 7. The cobble cover, kelp, urchins, anemones, cucumbers, and deepburrowing bivalves are all absent in the scoured sediment. Fauna dominating the scour are the small deposit feeding polychaetes Ophryotrocha spatula, Capitella cf. capitata, and the spionids Pygospio elegans and Prionospio steenstrupi, and crustaceans such as cumaceans, ostracods, and the predatory amphipod Monoculodes vibei. Clusters of the chainforming diatom Parlibellus sp. are abundant as well. Species dominance is high, and biomass is low. Despite differences in currents and depth, the Assistance and Resolute Bay scours harbored these scour-associated species as well.

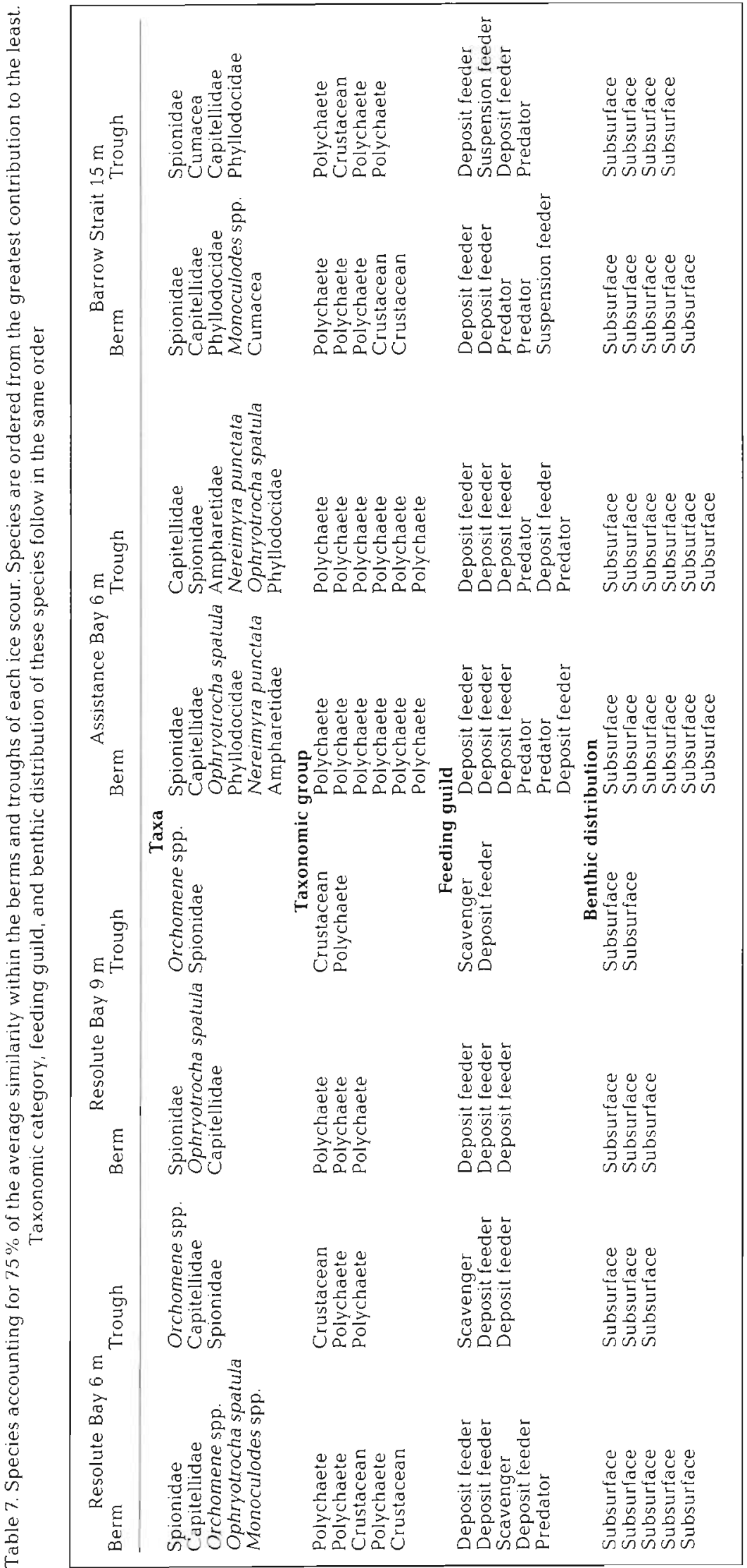


The presence of numerous polychaetes in the scours suggests either that there was rapid migration of adults and/or larval recruitment, or that these species survived the scouring event, possibly by being plowed up onto the berm and subsequently tumbling back into the trough. Spionid and capitellid polychaetes tolerate disturbance and are characteristic early colonizers of defaunated habitat (Grassle \& Grassle 1974, McCall 1977, Pearson \& Rosenberg 1978, Lenihan \& Oliver 1995, Olsgard \& Gray 1995, Warwick \& Clarke 1995). Species discrimination of the capitellid polychaetes indicated that Capitella cf. capitata predominated in the scour and inshore samples. Capitella cf. capitata has a small range of dispersal (Levin 1984) and can colonize local disturbances within days (Grassle \& Grassle 1974). It also requires enriched sediment for normal growth (Tsutsumi 1990). Spionids have prolonged spawning periods and relatively brief pelagic larval development. As adults they leave their tubes when disturbed, settling nearby to rapidly rebuild new tubes from the surrounding sediment (McCauley et al. 1976). The scours are patches of newly revealed clay, as well as sites of decomposition of buried fauna and depressions with different water properties (Kvitek et al. 1998). Movement of these polychaetes into patch depressions has been implicated as food related in other studies (Thistle 1981), and this is probably also the case for these ice scours. Various species of Monoculodes and Orchomene (primarily Monoculodes vibei and $O$. minutus) also dominated some scours. These are more mobile than the polychaetes, and could have been using the disturbed sediments to consume

Fig. 7. Dominant fauna (a) outside and (b) inside a 1 yr old scour in Barrow Strait at $20 \mathrm{~m}$ depth. The undisturbed seabed (a) is dominated in biomass by the large bivalves Mya truncata, Serripes groenlandicus, and Macoma calcarea, the sea urchin Strongylocentrotus pallidus, the sea cucumber Cucumaria frondosa, the anemone Telia sp., the polychaete Phyllodoce groenlandicus, and the kelp Agarum cribrosum. Dominant occupants of a 1 yr old scour berm (b) are tubicolous polychaetes [the spionids Prionospio steenstrupi and Pygospio elegans (vertical tubes) and Capitella cf. capitata (horizontal tube)l, the wandering polychaetes Ophryotrocha spatula (with spatulate posterior) and Nereimyra punctata, the amphipod Monoculodes vibei, and various cumaceans. Nemerteans and ostracods may also frequent new scours. Diatoms may colonize in abundance. The tufts shown here are composed of the tube-forming pennate diatom Parlibellus $\mathrm{sp}$.
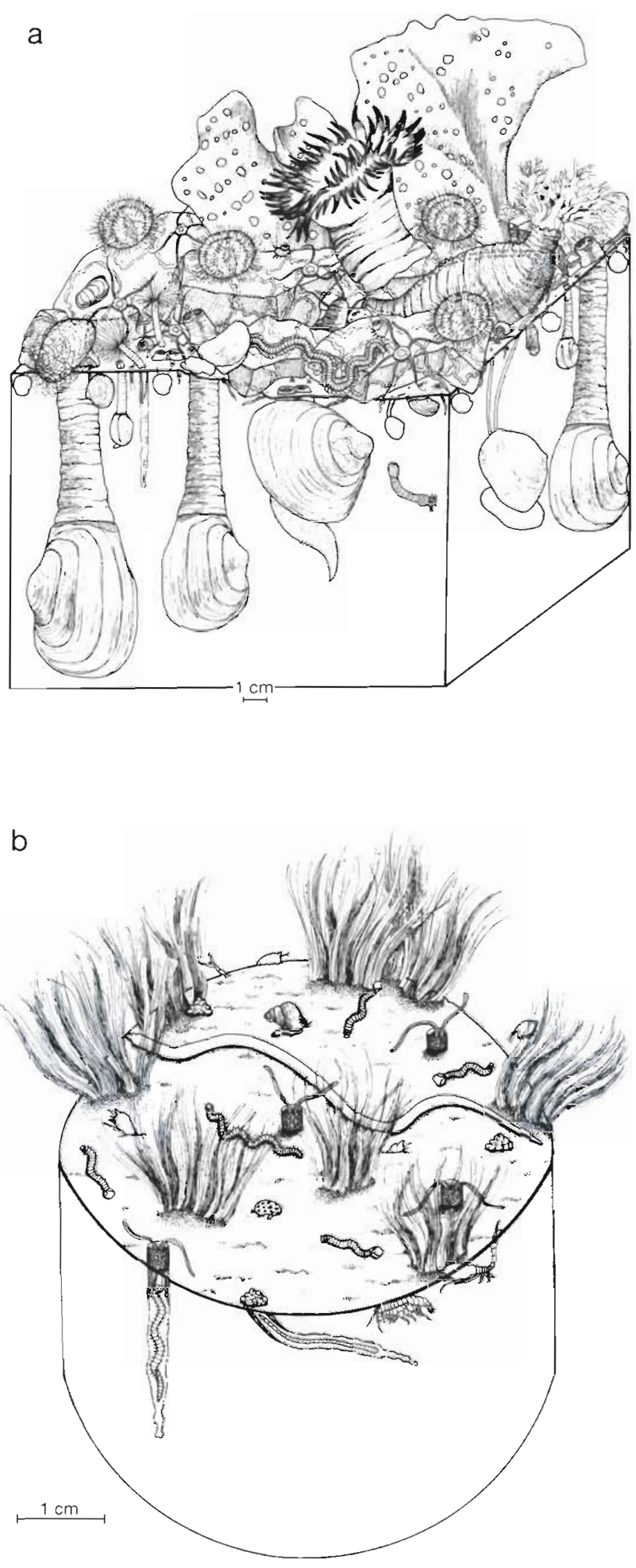
detritus, scavenge remains, and capture newly invading prey. The highly scoured inshore could serve as source areas for early recolonization of these offshore scours.

These results can be compared with several other studies of soft-bottom ice scouring. Similarities are evident. In McMurdo Sound, Antarctica, Lenihan \& Oliver (1995) found elevated numbers of Capitella sp. and Ophryotrocha claperedii in iceberg scours relative to unscoured sediment. Capitella cf. capitata and O. spatula were found to dominate scours in this study as well. In scours of soft mud on the Antarctic Peninsula, Kaufman (1977) found an initial increase of the large nemertean scavenger Parborlasia corrugatus, and mobile fauna recolonized quickly. Similarly, Gutt et al. (1996) found that the first immigrants of deep sea Arctic and Antarctic scours were mobile organisms such as fish, echinoderms, and bivalves. In this study, the first large epifauna to appear in new scours were buccinid gastropods and lysianassid amphipods, which scavenged the remains of damaged and uprooted fauna. Scours in crustacean-dominated sediment in the Bering Sea exhibited similar declines of fauna as seen in this study, but no infilling by opportunistic polychaetes and crustaceans (Klaus et al, 1990). However, Oliver \& Slattery (1985) found that the scavenging amphipods Anonyx spp. and Orchomene minutus invaded and attacked fauna dislodged by gray whale feeding, a finding similar to this study. These and many other lysianassid amphipods are cold water scavengers and are quick to be attracted to bait traps (Bousfield 1973, Slattery \& Oliver 1986, Conlan 1994).

The fact that the large bivalve Mya truncata did not achieve as great a size in the exposed Barrow Strait as in the protected Resolute Bay may be attributable to the frequency of ice disturbance, although other factors, such as current speed and sediment type, also differ. The $12 \mathrm{~m}$ sampling depth was outside the range of influence of ice in Resolute Bay but within range of deep draft ice in Barrow Strait. Peck \& Bullough (1993) found that ice scour limited the upper age attainable by a dense population of Yoldia eightsi at subantarctic Signy Island. Energetically, $M$. truncata is important to the Arctic benthos, filtering out phytoplankton and releasing it as undigested pseudofeces on the bottom, where it becomes available to deposit feeders (Welch et al. 1992). Individual $M$. truncata can attain. a high biomass but growth is slow. The oldest specimen aged for this region is $55 \mathrm{yr}$ (Welch et al. 1992).

Ice scouring is a large-scale event that affects Arctic and Antarctic coasts aljke. This study has shown that, although ice scouring is initially destructive, it provides opportunities as well. It alters seabed topography by gouging troughs and pushing up berms of sediment. It reveals fresh, cleared sediment, which is rapidly colonized by small polychaetes and amphipods. It also provides feeding opportunities for scavenging gastropods and amphipods. Depth-related faunal transitions along ice-scoured coastline may well predict the course of succession in offshore ice scours. Recently formed scours will resemble the inshore benthos, as illustrated in Fig. 7b, and gradually shift to resemble their same-depth counterparts outside, as shown in Fig. 7a. Many of the species that first colonize these scours are widespread in the Canadian Arctic. Congeners of these Arctic species also inhabit ice scours in Antarctica. Thus, the benthos may respond consistently wherever ice scour is a force.

Acknowledgements. We thank the following for their assistance: B. Konar with specimen collection, K. Carlson with specimen sorting, C. Biermann, J. Fournier, J.-M. Gagnon, E. Hendrycks, and A. Martel with species identifications, S. Laurie-Bourque with Fig. 7, G. Williams-Leir with preliminary statistical analyses, C. Malzone with current measurements, S. Blasco and G. Grant with Fig. 2, and S. Blasco and R. Myers with sidescan images. Critical review was provided by $M$. Graham, P. lampietro, S. Kim, C. Malzone, P. Slattery, and H. E. Welch. We are especially grateful to members of the Hamlet of Resolute Bay (H. Kalluk, N. Kalluk, I. Kalluk, and P. Amarualik), The Polar Continental Shelf Project, Natural Resources Canada (B. Hrycyk), and Fisheries and Oceans Canada (H. E. Welch) for logistic support. This work was licensed by the Nunavut Research Institute and the Baffin Region Inuit Association. Funding was provided by the Canadian Museum of Nature, the Royal Canadian Geographic Society, the National Geographic Society, and the National Science Foundation (OPP-9321504)

\section{LITERATURE CITED}

Aitken AE, Foumier J (1993) Macrobenthos communities of Cambridge, McBeth and Itirbilung Fiords, Baffin Island. Northwest Territories, Canada. Arctic 46:60-71

Barnes PW, Lien R (1988) Icebergs rework shelf sediments to $500 \mathrm{~m}$ off Antarctica. Geology 16:1130-1133

Barnes PW, Rearic DM, Reimnitz E (1984) Ice gouging characteristics and processes. In: Barnes PW, Schell DM, Reimnitz E (eds) The Alaskan Beaufort Sea. Ecosystems and Environments. Academic Press, Inc, Orlando, p $185-212$

Barnes PW, Reimnitz E (1974) Sedimentary processes on Arctic shelves off the north coast of Alaska. In: Reed JC, Slater JE (eds) The coast and shelf of the Beaufort Sea. Arctic Institute of North America, US Geological Survey, Calgary, AB, p 439-476

Barnes RD (1980) Invertebrate zoology, 4th edn. Saunders College, Philadelphia

Bélanger L, Bédard J (1994) Role of ice scouring and goose grubbing in marsh plant dynamics. J Ecol 82:437-445

Bélanger L, Bédard J (1995) Use of ice-scoured depressions by marsh-foraging snow geese (Chen caerulescens atlantica). Can J Zool 73:253-259

Bernard FR (1979) Bivalve mollusks of the western Beaufort Sea. Contrib Sci (Los Angel) 313:1-80

Bolton JJ (1983) Effects of short-term ice scouring on a Newfoundland rocky shore community. Astarte 12:39-43

Bond $G$, Heinrich $H$, Broecker W, Labeyrie L, McManus J, 
Andrews J, Huon S, Jantschik R, Clasen S, Simet C, Tedesco K, Klas M, Bonani G, Ivy S (1992) Evidence for massive discharges of icebergs into the North Atlantic Ocean during the last glacial period. Nature 360:245-249

Bousfield EL (1973) Shallow-water gammaridean Amphipoda of New England. Cornell University Press, Ithaca, NY

Bray JR, Curtis JT (1957) An ordination of the upland forest communities of Southern Wisconsin. Ecol Monogr 27. $325-349$

Brylinsky M, Gibson J, Gordon DC Jr (1994) Impacts of flounder trawls on the intertidal habitat and community of the Minas Basin, Bay of Fundy. Can J Fish Aquat Sci $51: 650-661$

Clark JI (ed) (1990) Workshop on ice scouring and design of offshore pipelines, Calgary, Alberta, April 18-19, 1990. Canada Oil and Gas Lands Administration, Energy, Mines and Resources Canada and Indian and Northern Affairs Canada, Ottawa

Clarke KR (1993) Non-parametric multivariate analyses of changes in community structure. Aust J Ecol 18:117-143

Clarke KR, Ainsworth M (1993) A method of linking multivariate community structure to environmental variables. Mar Ecol Prog Ser 92:205-219

Conlan KE (1994) Amphipod crustaceans and environmental disturbance: a review. J Nat Hist 28:519-554

Connell JH, Keough MJ (1985) Disturbance and patch dynamics of subtidal marine animals on hard substrata. In: Pickett STA, White PS (eds) The ecology of natural disturbance and patch dynamics. Academic Press, Orlando, p $125-151$

Currie DR, Parry GD (1996) Effects of scallop dredging on a soft sediment community: a large-scale experimental study. Mar Ecol Prog Ser 134:131-150

Curtis iviA (1972) Depth distributions of bonthic polychaetes in two fiords on Ellesmere Island, N.W.T J Fish Res Bd Can 29:1319-1327

DeLaca TE, Lipps JH (1976) Shallow-water marine associations, Antarctic peninsula. Antarct J US 11:12-20

Ellis DV, Wilce RT (1961) Arctic and subarctic examples of intertidal zonation. Arctic 14:224-235

Fauchald K, Jumars PA (1979) The diet of worms: a study of polychaete feeding guilds. Oceanogr Mar Biol Annu Rev $17: 193-284$

Fournier JA, Conlan KE (1994) A new species of Ophryotrocha (Polychaeta, Dorvilleidae) associated with ice scours in the Canadian Arctic Archipelago. In: Dauvin JC, Laubier L, Reish DJ (eds) Actes de la 4ème Conférence internationale des Polychètes. Mem Mus Natl Hist Nat 162:185-190

Gilbert G, Pedersen K (1987) Ice scour data base for the Beaufort Sea. Environmental Studies Revolving Funds Rep 55:1-99

Gordon DC Jr, Desplanque C (1983) Dynamics and environmental effects of ice in the Cumberland Basin of the Bay of Fundy. Can J Fish Aquat Sci 40:1331-1342

Grassle JF, Grassle JP (1974) Opportunistic life histories and genetic systems in marine benthic polychaetes. J Mar Res 32:253-284

Gutt J, Starmans A, Dieckmann G (1996) Impact of iceberg scouring on polar benthic habitats. Mar Ecol Prog Ser 137:311-316

Hall SJ (1994) Physical disturbance and marine benthic communities: life in unconsolidated sediments. Oceanogr Mar Biol Annu Rev 32:179-239

Heine JN (1989) Effects of ice scour on the structure of sublittoral marine algal assemblages of St. Lawrence and St. Matthew Islands, Alaska. Mar Ecol Prog Ser 52:253-260
Hooper RG, Whittick A. (1990) Seasonal seaweed community dynamics in a boreal/subarctic bay. Br Phycol J 25:90

Josenhans H, Woodworth-Lynas CMT (1988) Enigmatic linear furrows and pits on the upper continental slope, northwest Labrador Sea: are they sediment furrows or feeding traces? Mar Sed Atl Geol 24:149-155

Kauffman TA (1977) Seasonal changes and disturbance in an antarctic benthic mud community. $\mathrm{PhD}$ thesis, University of California, Davis

Keats DW, South GR, Steele DH (1985) Algal biomass and diversity in the upper subtidal at a pack-ice disturbed site in eastern Newfoundland. Mar Ecol Prog Ser 25:151-158

Keats DW, Steele DH, South GR (1984) Depth-dependent reproductive output of the green sea urchin, Stronylocentrotus droebachiensis (O.F. Müller), in relation to the nature and availability of food. J Exp Mar Biol Ecol 80:77-91

Klaus AD, Oliver JS, Kvitek RG (1990) The effects of gray whale, walrus, and ice gouging disturbance on benthic communities in the Bering Sea and Chukchi Sea, Alaska. Natl Geogr Res 6:470-484

Kruskal JB (1964) Multidimensional scaling by optimizing goodness of fit to a nonmetric hypothesis. Psychometrika 29:1-27

Kurian GT (ed) (1989) Geo-Data. The world geographical encyclopedia. Geo-Data Publications, New York

Kvitek RG, Conlan KE, Iampietro PJ (1998) Black pools of death: hypoxic, brine-filled ice gouge depressions become lethal traps for benthic organisms in a shallow Arctic embayment. Mar Ecol Prog Ser 162:1-10

Lambshead PJD, Platt HM, Shaw KM (1983) The detection of differences among assemblages of marine benthic species based on an assessment of dominance and diversity. J Nat Hist 17:859-874

Larson BR, Vadas RL, Keser M (1980) Feeding and nutritional ecology of the sea urchin Strongylocentrotus drobachiensis in Maine, USA. Mar Biol 59:49-62

Lenihan HS, Oliver JS (1995) Anthropogenic and natural disturbances to marine benthic communities in Antarctica. Ecol Appl 5:311-326

Levere TH (1993) Science and the Canadian Arctic. Cambridge University Press, New York

Levin LA (1984) Life history and dispersal patterns in a dense infaunal polychaete assemblage: community structure and response to disturbance. Ecology 65:1185-1200

Lewis CFM, Blasco SM (1990) Character and distribution of sea-ice and iceberg scours. In: Clark JI (ed) Workshop on ice scouring and design of offshore pipelines, Calgary, Alberta, April 18-19, 1990. Canada Oil and Gas Lands Administration, Energy, Mines and Resources Canada and Indian and Northern Affairs Canada, Ottawa, p 57-101

Lien R, Solheim A, Elverhîi A, Rokoengen K (1989) Iceberg scouring and sea bed morphology on the eastern Weddell Sea shelf, Antarctica. Polar Res 7:43-57

Lubinsky I (1980) Marine bivalve molluscs of the Canadian Central and Eastern Arctic: faunal composition and zoogeography. Can Bull Fish Aquat Sci 207:1-111

Macpherson E (1971) The marine molluscs of Arctic Canada. Nat Mus Natl Sci Publ Biol Oceanogr 3:1-149

Mathieson AC, Penniman CA. Busse PK, Tveter-Gallagher E (1982) Effects of ice on Ascophyllum nodosum within the Great Bay Estuary system of New Hampshire-Maine. J Phycol 18:331-336

McCall PL (1977) Community patterns and adaptive strategies of the infaunal benthos of Long Island Sound. J Mar Res 35:221-266 
McCauley JE, Hancock DR, Parr RA (1976) Maintenance dredging and four polychaete worms. In: Krenkel PA, Harrison J, Burdick JC IIJ (eds) Proceedings of the specialty conference on dredging and its environmental effects. American Society of Engineers, New York, p 633-64.4

McCook LJ, Chapman ARO (1993) Community succession following massive ice-scour on a rocky intertidal shore: recruitment, competititon and predation during early, primary succession. Mar. Biol 115:565-575

Messieh SH, Rowell TW, Peer DL, Cranford PJ (1991) The effects of trawling, dredging and ocean dumping on the eastern Canadian continental shelt seabed. Cont Shelf Res $11: 1237-1263$

Munro D (ed) (1988) Chambers world gazetter. Chambers, Cambridge

O'Clair CE (1981.) Disturbance and diversity in a boreal marine community: the role of intertidal scouring by sea ice. In: Hood DA, Calder JA (eds) The eastern Bering Sea shelf: oceanography and resources, Vol 2. NOAA, US Department of Commerce, Washington, DC, p 1105-1130

Oliver JS, Kvitek RG, Slattery PN (1985) Walrus feeding disturbance: scavenging habits and recolonization of the Bering Sea benthos. J Exp Mar Biol Ecol 91:233-246

Oliver JS, Slattery PN (1985) Destruction and opportunity on the sea floor: effects of gray whale feeding. Ecology 66: $1966-1975$

Olsgard $F$, Gray JS (1995) A comprehensive analysis of the effects of offshore oil and gas exploration and production on the benthic communities of the Norwegian continental shelf. Mar Ecol Prog Ser 122:277-306

Pearson TH, Rosenberg R (1978) Macrobenthic succession in relation to organic enrichment and pollution of the marine environment. Oceanogr Mar Biol Annu Rev 16:229-311

Peck LS, Bullough LW (1993) Growth and population structure in the infaunal bivalve Yoldia eightsi in relation to iceberg activity at Signy Island, Antarctica. Mar Biol 117 $235-241$

Pereira CPG, Piper DJW, Shor AN (1985) SeaMARC I midrange sidescan sonar survey of Flemish Pass, east of the Grand Banks of Newfoundland. Geological Survey of Canada Open File Report No. 1161

Petraitis PS, Latham RE, Niesenbaum RA (1989) The maintenance of species diversity by disturbance. $Q$ Rev Biol 64 . $393-418$

Pickett STA, White PS (1985) Patch dynamics: a synthesis. In: Pickett STA, White PS (eds) The ecology of natural disturbance and patch dynamics. Academic Press, Orlando, p 371-384

Reid RGB, Reid A (1969) Feeding processes of the genus Macoma (Mollusca: Bivalvia) Can J Zool 47:649-657

Reimnitz E, Barnes PW (1974) Sea ice as a geologic agent on the Beaufort Sea shelf of Alaska. In: Reed JC, Slater JE (eds) The coast and shelf of the Beaufort Sea. Arctic Institute of North America, US Geological Survey, Calgary

Reimnitz E, Barnes PW, Toimil L, Melchoir J (1977) Ice gouge recurrence and rates of sediment reworking, Beaufort Sea, Alaska. Geology 5:405-4.08

Rhoads DC, Boyer LF (1982) The effects of marine benthos on physical properties of sediments: a successional perspective. In: McCal.l PL, Tevesz M (eds) Animal-sediment relations. Plenum Press, New York, p 3-52

Robertson AI, Mann KH (1984) Disturbance by ice and life-history adaptations of the seagrass Zostera marina.
Mar Biol 80:131-141

Sekerek AD, Thomson D, Bain H. Acreman J (1976) Summer surveys of the marine ecology of Creswell Bay, Somerset Island and Assistance Bay, Cornwallis Island, N.W.T. 1975. Polar Gas Project, LGL Ltd. Environmenta] Research Associates, Toronto

Slattery PN, Oliver JS (1986) Scavenging and other feeding habits of lysianassid amphipods (Orchomene spp.) from McMurdo Sound, Antarctica. Polar Biol 6:171-177

Sokal RR, Mitchener CD (1958) A statistical method for evaluating systematic relationships. Univ Kans Sci Bull 38 $1409-1438$

Sousa WP (1984) The role of disturbance in natural communities. Annu Rev Ecol Syst 15:353-391

Sousa WP (1985) Disturbance and patch dynamics on rocky intertidal shores. In: Pickett STA, White PS (eds) The ecology of natural disturbance and patch dynamics. Academic Press, Orlando, p 101-124

Stanley SM (1970) Relation of shell form to life habits of the Bivalvia (Mollusca) Geol Soc Am Mem 125:1-296

Thistle D (1981) Natural physical disturbances and communities of marine soft bottoms. Mar Ecol Prog Ser 6:223-228

Thrush SF, Hewitt JE, Cummings VJ, Dayton PK (1995) The impact of habitat disturbance by scallop dredging on marine benthic communities: what can be predicted from the results of experiments? Mar Ecol Prog Ser 129:141-150

Tsutsumi H (1990) Population persistence of Capitella sp. (Polychaeta; Capitellidae) on a mud flat subject to environmental disturbance by organic enrichment. Mar Ecol Prog Ser 63:147-156

Vadas RL (1977) Preferential feeding: an optimization strategy in sea urchins. Ecol Monogr 47:337-371

VanBlaricom GR (1982) Experimental analyses of structural regulation in a marine sand community exposed to oceanic swell. Ecol Monogr 52:283-305

Warwick RM. Clarke KR (1993) Increased variability as a symptom of stress in marine communities. J Exp Mar Biol Ecol 172:215-226

Warwick RM, Clarke KR (1995) New 'biodiversity' measures reveal a decrease in taxonomic distinctness with increasing stress. Mar Ecol Prog Ser 129:301-305

Weeks WF, Barnes PW, Rearic DM, Reimitz E (1984) Some probabilistic aspects of ice gouging on the Alaskan shelf of the Beaufort Sea. In: Barnes PW, Schell DM, Reimnitz E (eds) The Alaskan Beaufort Sea. Ecosystems and environments. Academic Press, Inc, Orlando, p 213-236

Welch HE, Bergmann MA, Siferd TD, Martin KA, Curtis MF, Crawford RE, Conover RJ, Hop H (1992) Energy flow through the marine ecosystem of the Lancaster Sound region, Arctic Canada. Arctic 45:343-357

Weston DP (1990) Quantitative examination of macrobenthic community changes along an organic enrichment gradient. Mar Ecol Prog Ser 61:233-244

Wethey DS (1985) Catastrophe, extinction, and species diversity: a rocky intertidal example. Ecology 66:445-456

Wilson WH Jr (1988) Shifting zones in a Bay of Fundy softsediment community: patterns and processes. Ophelia 29: $227-245$

Woodworth-Lynas CMT, Guigné JY (1990) Iceberg scours in the geological record: examples from glacial Lake Agassiz. In: Dowdeswell JA, Scourse JD (eds) Glacimarine environments: processes and sediments. Geol Soc Spec Publ 53:217-223

Submitted: June 10. 1997; Accepted: March 13, 1998

Proofs received from author(s): May 4, 1998 